Santa Clara University

Scholar Commons

Economics

Leavey School of Business

9-3-2015

\title{
The recent growth of international reserves in developing economies: A monetary perspective
}

Gonçalo Pina

SantaClara University,gpina@scu.edu

Follow this and additional works at: http://scholarcommons.scu.edu/econ

Part of the Economics Commons

\section{Recommended Citation}

Pina, G. (2015). The recent growth of international reserves in developing economies: A monetary perspective. Journal of International Money and Finance, 58(Supplement C), 172-190. https://doi.org/10.1016/j.jimonfin.2015.08.009

(C) 2015. This manuscript version is made available under the CC-BY-NC-ND 4.0 license http://creativecommons.org/licenses/by-nc-nd/4.0/.

The final version of the paper can be found here - https://doi.org/10.1016/j.jimonfin.2015.08.009.

This Article is brought to you for free and open access by the Leavey School of Business at Scholar Commons. It has been accepted for inclusion in

Economics by an authorized administrator of Scholar Commons. For more information, please contact rscroggin@scu.edu. 


\title{
The Recent Growth of International Reserves in Developing Economies: A Monetary Perspective
}

\author{
Gonçalo Pina \\ Santa Clara University \\ Leavey School of Business, 500 El Camino Real, Santa Clara, California 95053
}

\begin{abstract}
The massive accumulation of international reserves in developing economies is a puzzling recent development in the world economy. This paper studies reserve accumulation as the outcome of a simple model in which the central bank smooths inflation. I explore the view that central banks accumulate reserves to face large fiscal shocks that need monetary financing. Central bank revenues are obtained through inflation, but inflation is distortionary. As a result, the central bank optimally accumulates international reserves in order to spread the costs associated with inflation over time. A simple numerical exercise for an average developing economy using data between 1970 and 2009 yields fast growth of international reserves.

Keywords: inflation tax, exchange rates, international reserves, monetary policy.
\end{abstract}

Email address: gpina@scu.edu (Gonçalo Pina) 


\section{Introduction}

The last 20 years have witnessed a large increase in international reserve holdings by central banks in developing economies. Figure 1 plots the evolution of reserves for developed and developing economies as a share of their GDP between 1970 and 2009. ${ }^{1}$ The most striking feature of this graph is the divergence between the two groups of countries between 1987 and 2009 . Following a relatively stable period of reserves to GDP ratios close to $10 \%$, since 1987 developed economies have been reducing their reserves relative to $G D P$. At the same time, developing economies have steadily increased their international reserves relative to GDP to a level that exceeded $20 \%$ in 2007 .

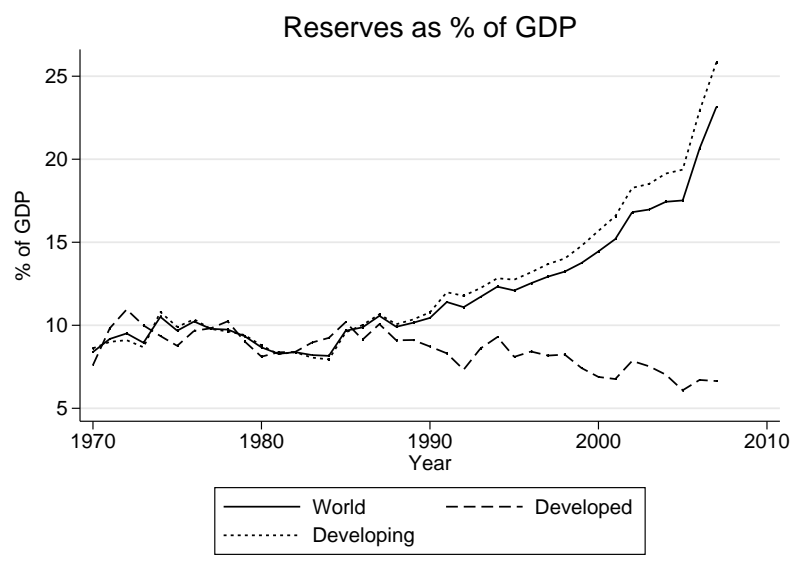

Figure 1: Unweighted cross-country averages of International Reserves (minus gold) as a share of GDP for 24 developed economies and 154 developing economies between 19702009. Source: author's calculations based on the World Development Indicators. More details in Online Appendix C.

\footnotetext{
${ }^{1}$ International reserves are defined as liquid external assets under the control of the central bank. This plot excludes holdings of gold.
} 
Why have central banks in developing countries increased their reserve holdings, in contrast to their developed-country counterparts? This accumulation has important implications. From the perspective of a developing economy, it represents foregone consumption and investment in countries with good growth prospects. From the perspective of the global economy, reserves have played a role in the emergence of upstream capital flows - from poor to rich countries - and contributed to global imbalances. This paper takes a monetary view on this phenomenon and studies reserve accumulation by a central bank looking to smooth inflation.

I set up the problem of a central bank that has to finance exogenous and stochastic spending shocks with inflation. I interpret these shocks as banking sector support during a banking crisis. The central bank is a Ramsey planner, and maximizes the utility of the private agent. Inflation is distortionary and therefore the central bank wishes to spread distortions over time. To do so, it accumulates reserves in order to smooth inflation against these shocks.

Figure 2 shows the incidence of banking crises in the last 40 years. The blue bars plot the frequency of banking crises in the world economy during 5 -year windows. These crises were particularly frequent in the last 20 years. ${ }^{2}$ Banking crises were also very costly. The numbers on top of the gray bars represent the median fiscal cost of banking crises in percentage of $G D P$ for each 5-year window. A substantial fraction of these fiscal shocks

\footnotetext{
${ }^{2}$ Reinhart and Rogoff (2008) show that banking crises are not exclusive to the last two decades. Between the late 1890 and the early 1930s there was a similar incidence of banking crises across the world economy. They associate these events to increases in capital mobility (see Figure 3 in their paper).
} 


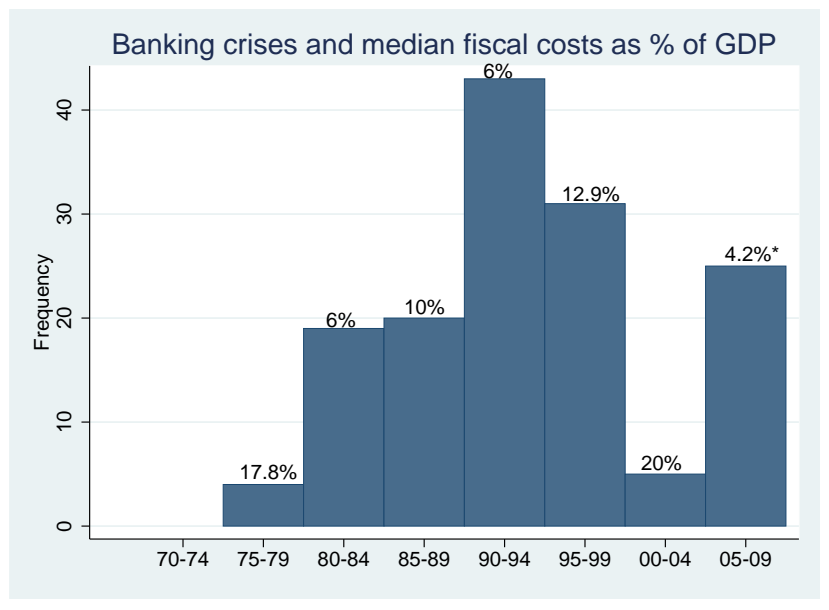

Figure 2: Frequency of crises and median fiscal cost (gross, as \% of GDP; ${ }^{*}$ crises ongoing) between 1970-2011, for all countries. Measure for fiscal cost is only available for selected crises and is cumulative. The median duration of a crisis in the sample is 3 years. Source: Laeven and Valencia (2013). See Table 2 in Section 4.1. for available data on the portion of these costs that needs to be financed with inflation related revenues.

are financed with inflation related revenues. Available estimates of inflation related revenues amount to $10 \%$ of $G D P$, in episodes where the total fiscal cost ranges between 15 and $65 \%$ of GDP (Burnside et al. (2001), Burnside et al. (2006)). It is also possible to find examples of central bank support to the banking sector that require the central bank to hold liquid foreign assets. For example, in its 2008 annual report, the Russian central bank states that "funds provided by the Bank of Russia to maintain banking sector stability in September-December exceeded 9\% of GDP", and justifies the decrease of international reserves with operations in the domestic foreign exchange market, as well as with direct support to the banking system. ${ }^{3}$

\footnotetext{
${ }^{3}$ Looking at a larger sample between 1970 - 2011, Laeven and Valencia (2013) show
} 
Ultimately, what matters for the central bank are prospective crises, not realized crises. In this paper I argue that, starting in the late 1980s, the need to provide banking sector support in periods of crisis required a new assessment of international reserves adequacy by central banks in developing economies. Empirical research has noted the correlation between the size of the financial sector and reserves. Lane and Burke (2001) are the first to document the correlation between M2/GDP and reserves in a purely cross sectional analysis. Obstfeld et al. (2010) perform a panel analysis and argue that in developing economies larger M2/GDP has a positive causal impact on reserves, and that managed exchange rate mechanisms are correlated with reserves. Similar to my paper, they interpret reserves as highly liquid foreign savings to support the banking sector through bailouts while avoiding currency depreciation.

The model predicts exchange rate behavior that is consistent with the evidence. Large stocks of international reserves have been associated with undervalued exchange rates. In the model, the central bank accumulates international reserves resorting to inflation. ${ }^{4}$ As a consequence, the value of

that the median cumulative fiscal costs as a share of current GDP were $4.5 \%$ for advanced economies and $10.0 \%$ for developing economies. They do not differentiate between fiscal and monetary financed costs. They do show that developed economies rely more on increases in public debt following a banking crisis, as the median increase in debt as a share of GDP was $23.6 \%$ for advanced economies, and 10.2\% for developing economies. The authors also discuss monetary interventions such as monetary expansion and liquidity support. Section 4 discusses the available data and gives more examples of central bank support to the banking sector.

${ }^{4}$ The model abstracts from the role of sterilization policy, by assuming that domestic 
domestic currency decreases relative to foreign currencies. In other words, the nominal exchange rate depreciates during the accumulation process. When a crisis occurs, the central bank deploys its reserves to finance the banking sector. This sustains the value of domestic currency and keeps the exchange rate from collapsing. This is consistent with empirical work by Aizenman and Sun (2012) and Dominguez et al. (2012). These papers show that countries drew from their reserves during the 2008 crisis. Obstfeld et al. (2009) show further that countries with larger international reserve holdings saw a smaller depreciation of their currencies during 2008.

The view explored in this paper can shed light on the divergence between the two groups of economies in Figure 1. Developed economies are less dependent on international reserves because $(i)$ they rely less on inflation related revenues as the government can issue more public debt following a financial crisis, and (ii) their central banks have access to contingent borrowing in times of crisis. There is also substantial heterogeneity within countries that accumulate reserves. Although most developing countries have accumulated international reserves, Figure 1 masks substantial cross-sectional variation. In the quantitative section of the paper I perform a series of exercises to study the sources of cross-sectional variation in reserve accumulation. I find that the most important determinants of the stock of international reserves are the size of a crisis and the existence of borrowing constraints. The frequency with which crises occur is less important. This indicates that countries with

debt and foreign debt are perfect substitutes for domestic agents. This implies that printing money is always inflationary. See Brutti (2011) and Gennaioli et al. (2014) for open economy models where domestic agents prefer to hold domestic government bonds. 
larger banking sectors and that have less access to external finance should have more international reserves.

The recognition that reserve holdings are a crucial instrument for policy in open economy models dates back to the literature on balance of payments crises in economies with fixed exchange rates - notably, Krugman (1979), Flood and Garber (1984) and Broner (2008). In these papers, the level of reserves determines the duration of an unsustainable exchange rate peg. Calvo (1987) provides microeconomic foundations and studies the dynamics of balance of payments crises in an economy with maximizing agents that demand money due to a cash-in-advance constraint. Subsequent work by Burnside et al. (2001), Kumhof et al. (2010), Rebelo and Végh (2008) and Rigobon (2002) analyzes economic policy in this model. Although these papers study policy where reserves are endogenously depleted, the accumulation of reserves is not analyzed. The main differences in my paper are that I study an economy that is not yet in crisis, and where the central bank takes into account the magnitude of a prospective crisis and the distortions associated with inflation when accumulating international reserves. ${ }^{5}$

\footnotetext{
${ }^{5}$ Burnside et al. (2001) argue that the Asian crisis of 1997 was caused by prospective deficits associated with implicit guarantees to failing banks, to be financed with inflation related revenues. The reserve accumulation model I explore in this paper shares the same perspective on monetary policy. Faced with the possibility of future deficits, but in a situation with strong economic conditions, a central bank accumulates reserves to avoid future large swings in inflation and exchange rates. Kumhof et al. (2010) extends the analysis to different ad-hoc inflation and exchange rate mechanisms to explore their quantitative implications. Rebelo and Végh (2008) study the optimal time to abandon a fixed exchange rate mechanism. Rigobon (2002) studies the problem of a central bank
} 
A recent literature studies optimal accumulation of international reserves as precautionary savings or insurance in order to smooth aggregate consumption. This perspective, developed for example by Alfaro and Kanczuk (2009), Durdu et al. (2009), Jeanne and Ranciere (2011) and Bianchi et al. (2014), considers that developing economies depend on short-term capital inflows. Countries accumulate foreign assets to sustain consumption when there are negative output shocks and access to international financial markets is interrupted, a view that has been synthesized by the Guidotti-Greenspan rule (Greenspan (1999)). This rule states that the ratio of reserves to short-term debt should be 1 . This literature points to short-term debt as a crucial determinant of reserves and obtains long-run mean levels of reserves consistent with the data (Jeanne and Ranciere (2011) and Bianchi et al. (2014)). Turning to empirical work, Bussière et al. (2015) argue that short term debt is the most significant metric for international reserves, while Obstfeld et al. (2010) favor an interpretation based on financial stability and exchange rates.

The monetary perspective presented in this paper shares the view that reserves are held due to insurance or precautionary motives. But there are important differences with the consumption smoothing literature. I focus on the problem of one big agent, the central bank, that interacts with the rest of the economy. The central bank accumulates reserves in order to achieve inflation smoothing, and to smooth the distortions associated with transferring resources within the economy. In this sense, my paper is closest to the analysis of Aizenman and Marion (2004), who study political-economy

that draws from its reserves to reap benefits from a future fiscal reform. 
considerations in a model where a government decides between reserves and distortionary taxation, and the literature on tax smoothing introduced by Barro (1979). In Barro's economy, the optimal tax policy is for the government to smooth taxes over time. This policy is the consequence of convex costs associated with distortionary taxes. I take this insight and embed it in a open economy monetary model to study international reserve policy by the central bank.

The paper proceeds as follows: Section 2 introduces the monetary model and describes the central bank problem. In Section 3 I solve for a deterministic example that allows for a closed form solution, and develop the main intuitions of the model. Section 4 studies the quantitative predictions of the model. Finally, Section 5 concludes and points to future research.

\section{A monetary model of reserve accumulation}

The model presents an economy where a representative consumer and a central bank use a non-contingent bond to smooth exogenous stochastic shocks. I focus on the the problem of the central bank. The central bank dislikes inflation but has financial responsibilities in the form of foreign currency. To finance these, the central bank can use two instruments: (i) it can raise inflation related revenues or (ii) it can withdraw from its international reserves. Because inflation is distortionary, the central bank wishes to spread the burden of inflation across time. As a result, it accumulates reserves in non-crisis periods and when necessary, uses a mix of inflation and reserves. 


\subsection{Setup}

Consider a small open economy with one traded good. Time is continuous. There are two maximizing agents: an infinitely lived representative consumer and a central bank. At any moment in time, the economy is either in a crisis state $(H)$, or in a non-crisis state $(L)$. The difference between the two is the amount of funds demanded from the central bank to support the government. For simplicity, I assume these resources are not transferred back to domestic agents. I now describe the problem of each agent in this economy.

The representative consumer maximizes the expected lifetime utility from the consumption plan $\left\{c_{t}\right\}_{0}^{\infty}$. The objective function of the consumer is given by:

$$
E_{0} \int_{0}^{\infty} \ln \left(c_{t}\right) e^{-\beta t} d t
$$

where $\beta>0$ is the consumer's subjective discount factor. I assume it to be equal to the foreign real interest rate $\rho$. The consumer can invest in an inflation index domestic bond, in a risk free foreign bond or in money holdings. The foreign bond earns the foreign real interest rate $\rho$, that is assumed to be constant. Given that domestic bonds are inflation indexed, domestic and foreign debt are perfect substitutes for the consumer. Let $f$ represent the total amount of domestic and foreign bond holdings. The consumer has log-utility and therefore just rolls over his initial wealth. These assumptions simplify the consumer's portfolio decision in order to focus on the problem of the central bank. The consumer can also invest in money holdings $M_{t}$. Money is introduced in this economy through a cash-in-advance constraint on consumption. This asset is useful for consumption purposes, 
but loses value with inflation. The opportunity cost of holding money is given by the nominal interest rate, which corresponds to the loss of value due to inflation plus the foregone return from not saving in the foreign bond.

Let $P_{t}$ be the domestic price level at $t$. The domestic inflation rate is given by $\pi_{t}=\dot{P}_{t} / P_{t}$, and assume the international inflation rate to be zero. Throughout, I assume that purchasing power parity holds $(P P P)$ such that the exchange rate is determined by inflation. Given that all debt is indexed to domestic inflation, the nominal domestic interest rate is given by: $i_{t}=\rho+\pi_{t}$. The flow budget constraint of the consumer can be written as $\dot{f}_{t}+\frac{\dot{M}_{t}}{P_{t}}=$ $\rho f_{t}+y-c_{t}$.

Additionally, the consumer faces a cash-in-advance constraint. To consume $\alpha c_{t}$ units of the consumption good, he must have real money holdings $\frac{M_{t}}{P_{t}}$ at least larger than $\alpha c_{t}$, where $\alpha$ is the proportion of consumption paid with money. The cash-in-advance constraint is given by:

$$
\alpha c_{t} \leq \frac{M_{t}}{P_{t}}
$$

Define $a_{t}=f_{t}+\frac{M_{t}}{P_{t}}$ as the wealth of the consumer in real terms. Because consumers only care about real balances, define real money balances as $m_{t}=$ $\frac{M_{t}}{P_{t}}$. As a store of value, money is always dominated by foreign assets if $i_{t}=\pi_{t}+\rho \geq 0$, which I assume throughout. Thus, the cash-in-advance constraint (2) will always hold with equality and money demand is given by $m_{t}=\alpha c_{t}$. I can then rewrite the flow budget constraint as

$$
\dot{a}_{t}=\rho a_{t}+y-\left(1+\alpha \pi_{t}+\alpha \rho\right) c_{t}
$$

Finally, the consumer's solvency condition is given by: 


$$
\lim _{t \rightarrow \infty} a_{t} e^{-\beta t} \geq 0
$$

The problem of the consumer is then to choose a sequence of $\left\{c_{t}\right\}_{0}^{\infty},\left\{a_{t}\right\}_{0}^{\infty}$, so as to maximize (1), subject to the flow budget constraint (3) and the solvency condition (4), given $\left\{\pi_{t}\right\}_{0}^{\infty}, f_{0}, \mathrm{y}$ and $m_{0}$. Under these assumptions, the solution to the consumer's problem is given by:

$$
\begin{array}{r}
c_{t}=\frac{y+\rho a_{0}}{1+\alpha \pi_{t}+\alpha \rho} \\
m_{t}=\alpha \frac{y+\rho a_{0}}{1+\alpha \pi_{t}+\alpha \rho}
\end{array}
$$

The intuition behind equations (5) is the following. Under log-utility the inter-temporal elasticity of substitution is 1 . If $\beta=\rho$ the consumer is just as patient as the international market. Therefore, the consumer spends the same amount of resources $y+\rho a_{0}$ in every period to finance his consumption expenditures $\left(1+\alpha \pi_{t}+\alpha \rho\right) c_{t}$, independently of the cost of consumption at $t$. In this simple setting, the elasticity of savings to the interest rate is zero.

For a given inflation policy, this model is a traditional small open economy model and can be used to study consumption and capital flows. In this paper, I am interested in optimal inflation policy and reserve management, and their implications for the aggregates in the economy. We now turn to the problem of the central bank.

\subsection{The central bank problem}

I assume the central bank to be benevolent. It solves a constrained optimization problem: subject to the demands of the government, the consumer's choices and it's own budgetary constraints, the central bank maximizes the 
representative consumer's utility. The solution is represented by a timeconsistent contingent plan for the inflation rate $\left\{\pi_{t}\right\}_{0}^{\infty}$ that maximizes (1).

The central bank can tax the consumer through inflation. With the resources obtained from seigniorage $\dot{M}_{t} / P_{t}$, the central bank can pay for banking sector support $g_{t}$ or accumulate net international reserves $r_{t}$ that earn interest $\rho$. Absent any borrowing constraint, the central bank can also borrow from the international bond market at rate $\rho$. Therefore, reserves $r_{t}$ capture the net foreign position of the central bank. However, since this asset is not contingent on shocks to $g_{t}$, the central bank does not have access to perfect insurance. The external budget constraint of the central bank is given by: $\dot{r}_{t}=\rho r_{t}+\dot{M}_{t} / P_{t}-g_{t}$. Given that $\dot{M}_{t} / P_{t}=\dot{m}_{t}+\pi m_{t}$, we can rewrite this constraint as $\dot{r}_{t}=\rho r_{t}+\dot{m}_{t}+\pi_{t} m_{t}-g_{t}$.

In exchange for the financing $g_{t}$ the central bank gets domestic debt $b_{t}$, either issued by the government or from financial institutions. The balance sheet of the central bank is then given as: $b_{t}+r_{t}=m_{t}$, where $b_{t}+r_{t}$ are the assets, and $m_{t}$ corresponds to its liabilities. The budget constraint of the central bank can be rewritten as: ${ }^{6}$

$$
\dot{b}_{t}=\rho b_{t}+g_{t}-\left(\pi_{t}+\rho\right) m_{t}
$$

The central bank may face a constraint on how much debt it can issue abroad. I introduce this through an exogenous borrowing constraint given by $r_{t} \geq \underline{r}=0$. Note that this constraint is on central bank issued debt and

\footnotetext{
${ }^{6}$ Further details can be found in the Online Appendix A.1. The focus on a fully backed money supply is done for analytical convenience and is not crucial for the results in this paper.
} 
should not be confused with the government or the financial sector external funding constraints.

Note that the assumptions of PPP, indexed debt and perfect capital mobility imply that choosing inflation $\pi_{t}$ is the same as choosing $i_{t}$. Since international inflation is zero, exchange rate depreciation tracks one to one the inflation rate. That is, when inflation increases, the value of the domestic currency loses value and the exchange rate depreciates. When choosing the inflation rate, the central bank takes into account the impact of its decisions on the representative consumer. In particular, the solution to the representative consumer problem given by (5) is a constraint in the optimal policy problem of the central bank. The central bank is effectively a Ramsey planner.

Absent any spending demands $g_{t}$, the optimal policy of an unconstrained central bank is given by the Friedman rule, with $i_{t}=0$ and $\pi_{t}=-\rho$. However, $g_{t}$ will occasionally be large and the central bank will have to resort to inflation. To keep the analysis simple, I study the case where $g_{t}$ takes one of two values $\left\{g_{L}, g_{H}\right\}$, and evolves according to the following Poisson process:

$$
g_{t+d t}=\left\{\begin{array}{rrrr}
g_{L} & \text { w.p. } & 1-q_{L} d t & \text { if } g_{t}=g_{L} \\
g_{H} & \text { w.p. } & q_{L} d t & \text { if } g_{t}=g_{L} \\
g_{H} & \text { w.p. } & 1-q_{H} d t & \text { if } g_{t}=g_{H} \\
g_{L} & \text { w.p. } & q_{H} d t & \text { if } g_{t}=g_{H}
\end{array}\right.
$$

This economy will be in one of two states of nature, defined by $g_{H}>>g_{L}$. At any non-crisis period, a crisis arrives with probability $q_{L}$ and leaves with 
probability $q_{H}$. Because crises are relatively less frequent than safe periods, $q_{H}>>q_{L}$. This framework captures in a parsimonious way the type of shocks that I am studying: infrequent but severe crisis. We are now ready to study the optimal policy problem. At any $t$, the central bank takes as given $a_{0}$ and $b_{0}$ and solves:

$$
\begin{aligned}
\max _{\left\{\pi_{t}\right\}} E_{0} \int_{0}^{\infty} \ln \left(c_{t}\right) e^{-\rho t} d t \\
\text { s.t. } \\
\dot{b}_{t}=\rho b_{t}+g_{t}-\left(\pi_{t}+\rho\right) m_{t} \\
c_{t}=\frac{y+\rho a_{0}}{1+\alpha \pi_{t}+\alpha \rho} \\
m_{t}=\alpha \frac{y+\rho a_{0}}{1+\alpha \pi_{t}+\alpha \rho} \\
r_{t}=m_{t}-b_{t} \\
\lim _{T \rightarrow \infty} b_{T} e^{-\rho T}=0, \quad a_{0}, b_{0} \text { given } \\
g_{t} \text { given by }(7) \\
r_{t} \geq \underline{r}
\end{aligned}
$$

Suppose the economy starts in a period with low $g_{t}$, but the central bank knows it might face a crisis soon, and an increase in $g_{t}$. Faced with a banking crisis the central bank can either print money or draw from its reserves. Printing money causes inflation which decreases consumption, but the consumer has a concave utility. It follows that the optimal policy of the central bank is to smooth inflation. 
The extent to which it can smooth inflation depends on the existence of constraints on how much the central bank can borrow abroad. If the central bank is unconstrained, the crisis will be financed mostly with future revenues and the central bank need not accumulate many reserves. On the other hand, if there is a constraint, this limits the amount of future revenues a central bank can transfer to the crisis period thus increasing precautionary savings ex-ante. ${ }^{7}$

The optimal policy problem can be described with two value functions, one for each state $j=L, H$, subject to the relevant constraints. Given state $j$, the relevant state variable of the economy is summarized by $b_{t}$. There are four constraints in the central bank problem. First, the budget constraint which is summarized by equation (6). Second, the borrowing constraint on reserves $r_{t} \geq \underline{r}$. Finally, the optimal decisions of the consumer given by (5). I represent the problem using the following value functions, where I omit the subscripts $t$ and the state variables to simplify notation:

\footnotetext{
${ }^{7}$ In the model, foreign reserves are net of foreign debt of the central bank. There are some cases of central banks issuing debt and accumulating reserves - for example, the Monetary Stabilization Bonds issued by the Bank of Korea in 2004, and the establishment of emergency swap lines between central banks during the 2008 crisis. Note also that throughout the debt position of the fiscal authority is taken as given and the paper makes no statement about the public sector's net foreign asset position. For theoretical papers on the public sector's gross and net foreign asset positions see Alfaro and Kanczuk (2009) and Bianchi et al. (2014). See Broner et al. (2013) and Forbes and Warnock (2012) for empirical works on the behavior of gross flows.
} 


$$
\rho V^{L}=\max _{\pi^{L}} \ln \left(\frac{y+\rho a_{0}}{1+\alpha \pi^{L}+\alpha \rho}\right)+V_{b}^{L}\left(\rho b+g_{L}-\left(\frac{\alpha\left(\pi^{L}+\rho\right)\left(y+\rho a_{0}\right)}{1+\alpha \pi^{L}+\alpha \rho}\right)+q_{L} \cdot\left(V^{H}-V^{L}\right)\right.
$$

for the low expenditure state, and

$$
\rho V^{H}=\max _{\pi^{H}} \ln \left(\frac{y+\rho a_{0}}{1+\alpha \pi^{H}+\alpha \rho}\right)+V_{b}^{H}\left(\rho b+g_{H}-\left(\frac{\alpha\left(\pi^{H}+\rho\right)\left(y+\rho a_{0}\right)}{1+\alpha \pi^{H}+\alpha \rho}\right)+q_{H} \cdot\left(V^{L}-V^{H}\right)\right.
$$

for the high expenditure state, where $V^{j}$ is the value function of the central bank for states $j=\{L, H\}$ with boundary conditions: $\lim _{b \rightarrow-\infty} i^{j}=-\frac{1}{\alpha}-$ $\rho$. The Online Appendix A.2 describes the details of the solution to this problem. It shows that if $\underline{r}=-\infty$ this problem can be rewritten as the solution of the following system of differential equations:

$$
\begin{gathered}
\frac{\partial \pi^{L}}{\partial b}=\frac{q^{L}\left(\pi^{L}-\pi^{H}\right)}{\rho b+g_{L}-\left(\pi^{L}+\rho\right)\left(\alpha \frac{y+\rho a_{0}}{1+\alpha \pi^{L}+\alpha \rho}\right)} \\
\frac{\partial \pi^{H}}{\partial b}=\frac{q^{H}\left(\pi^{H}-\pi^{L}\right)}{\rho b+g_{H}-\left(\pi^{H}+\rho\right)\left(\alpha \frac{y+\rho a_{0}}{1+\alpha \pi^{H}+\alpha \rho}\right)} \\
\lim _{b \rightarrow-\infty} \pi^{L}=-\frac{1}{\alpha}-\rho \lim _{b \rightarrow-\infty} \pi^{H}=-\frac{1}{\alpha}-\rho
\end{gathered}
$$

If $\underline{r} \neq-\infty$ there is an additional boundary condition. When reserves hit the constraint, the central bank is forced to float and to finance all $g_{t}$ with current inflation revenues. In the setting considered in this paper this will only happen in the high state. The problem given by equation (9) is then augmented with the constraint: $\pi_{t}^{H} \geq \bar{\pi}^{H}$, where $\left(\bar{\pi}^{H}, \bar{b}\right)$ is the solution to: 


$$
\begin{gathered}
\frac{y+\rho a_{0}}{1+\alpha \bar{\pi}^{H}+\alpha \rho}=g_{H}+\rho \bar{b} \\
\frac{y+\rho a_{0}}{1+\alpha \bar{\pi}^{H}+\alpha \rho}=\bar{b}+\underline{r}
\end{gathered}
$$

This problem does not admit a closed form solution and in Section 4 I explore the quantitative implications of the model. Before, the next section develops intuitions resorting to a deterministic example.

\section{Building intuitions}

\subsection{Deterministic example}

To make the trade-offs associated with reserve management clear, I focus on a deterministic example that admits a closed form solution. In particular, consider that the expenditure process can be summarized by the following expression:

$$
g_{t+d t}=\left\{\begin{array}{rrr}
0 & \text { if } & t<t_{1} \\
g & \text { if } & t_{1} \leq t \leq t_{2} \\
0 & \text { if } & t>t_{2}
\end{array}\right.
$$

that is, at $t=0$, the central bank learns that an increase in spending will occur between $t_{1}$ and $t_{2}$. Faced with this new information, the central bank must reexamine the adequacy of its current reserve stocks. To simplify the analysis, assume further that $\alpha=1$. 


\subsection{No constraint on reserves}

Define a balanced budget inflation rate as the policy from a naive central bank that contemporaneously finances $g_{t}$ with inflation. That is, where $b_{t}=$ 0. In this policy reserve holdings will not be optimal and there will be fluctuations in crucial variables such as consumption and the inflation rate. Because it implies flexible exchange rates, I also refer to it as the "flexible benchmark". I will represent the flexible inflation rate as $\pi_{f}$, for flexible. Replacing the optimal decision of the consumer on the central bank budget

constraint: $\dot{b}_{t}=\rho b_{t}+g_{t}-\frac{y+\rho a_{0}}{1+\rho+\pi_{t}}\left(\rho+\pi_{t}\right), \forall_{t}$, which can be rewritten as:

$$
\frac{1}{1+\rho+\pi_{f}^{L}}=1-\frac{\rho b_{0}}{y+\rho a_{0}}>\frac{1}{1+\rho+\pi_{f}^{H}}=1-\frac{g+\rho b_{0}}{y+\rho a_{0}},
$$

If the policy of the central bank is to finance government spending only through contemporaneous inflation, then consumption and reserves fluctuate with government spending. For each $j=L, H$ and all $t$ :

$$
\begin{aligned}
& c_{t}^{j}=y+\rho a_{0}-\left(g_{t}^{j}+\rho b_{0}\right) \\
& r_{t}^{j}=y+\rho a_{0}-\left(g_{t}^{j}+\rho b_{0}\right)-b_{0}
\end{aligned}
$$

Equation (12) shows that the domestic interest rate is larger in periods when $g_{t}$ is large, which translates into larger inflation. Equation (13) shows that consumption is lower in these periods. The path of these variables is plotted in Figure 3. In this economy, the central bank increases inflation in periods with high expenditure, and decrease inflation in periods with low expenditure. Inflation is very volatile and reserves are completely determined by initial conditions and the state of the economy. Because inflation 
is distortionary and distortions have convex costs, the higher the volatility of inflation, the higher are the welfare costs associated with the naive flexible policy. A central bank behaving optimally steers away from large and volatile inflation. It chooses reserves in order to stabilize inflation, and minimize distortions and welfare costs.

To show this, I first assume that there is no constraint on borrowing by the central bank $(\underline{r}=-\infty)$ and then that reserves can never be negative $(\underline{r}=0) .{ }^{8}$ Since the crisis is expected and there is no constraint on reserves, the optimal solution is to have a constant interest rate. This yields an optimal $c_{t}$ that is constant:

$$
\begin{gathered}
c^{*}=y+\rho a_{0}-\rho\left(G+b_{0}\right) \\
\pi^{*}=\frac{\rho\left(G+b_{0}\right)}{y+\rho a_{0}-\rho\left(G+b_{0}\right)}-\rho
\end{gathered}
$$

where $G$ is the present value of expenditure, $G=\rho^{-1}\left(e^{-\rho t_{1}}-e^{-\rho t_{2}}\right) g$.

The (constant) inflation tax will depend on the amount of resources that need to be financed and on the initial wealth of the central bank. Furthermore, it will depend on how wealthy the representative consumer is. Figure 3 plots the solution of the model. ${ }^{9}$ It is possible to see that the optimal solution to an expected crisis when there is no borrowing constraint is to smooth

\footnotetext{
${ }^{8}$ The detailed solution for the case without a borrowing constraint can be found in the Online Appendix B.1.

${ }^{9}$ These figures are computed with the following parameterization: $\rho=\beta=0.05, y=\frac{2}{3}$, $a_{0}=-0.55, g_{L}=0, g_{H}=0.1, b_{0}=0.5, b_{1}^{f}=0.5135, r_{0}=0.1$. The timing of the crisis is the following: $g_{t}=g_{H}$ between $t_{1}=5$ and $t_{2}=10$, and $g_{t}=g_{L}=0$ elsewhere.
} 

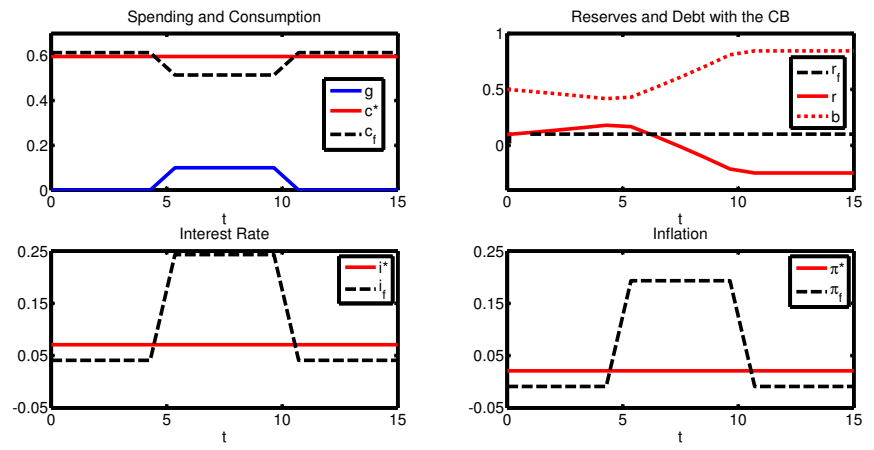

Figure 3: The qualitative benefits of reserve management: the unconstrained economy under balanced budget $(f)$ and optimal inflation rates $(*)$ faced with a predictable increase in expenditure.

inflation perfectly. Inspecting the lower panels shows that this is achieved with a constant and positive inflation rate. The upper right panel shows the behavior of reserves $(r)$. Initially, the central bank accumulates some reserves to face the crisis, but around $t=7$, starts borrowing from abroad. Once the crisis is over, the central bank keeps reserves constant.

Consider two alternative policies. First assume that the central bank wishes to keep reserves always constant. Before $t_{1}$ we have that $g=0$ so the inflation rate that implements this policy is the same as in the flexible benchmark: $\pi_{f}^{L}$. What about once $g$ is positive? To keep reserves constant and still pay for $g$, the central bank needs now to inflate the economy further, even more than $\pi_{f}^{H}$. Once $g$ goes back to zero, the central bank drastically reduces the inflation rate and gradually increases it back to a constant level. A policy of constant reserves is therefore qualitatively similar to a flexible 
policy, except that it translates into even larger fluctuations in inflation and consumption, and therefore, into larger welfare costs.

Assume now that the central bank would like to implement a fixed exchange rate policy. Under a fixed exchange rate, $\pi_{t}=0$ and $i_{t}=\rho$. Under this policy consumption is also constant at $c^{\text {fixed }}=\frac{y+\rho a_{0}}{1+\rho}$. It remains to see if this policy is feasible. Given $c^{\text {fixed }}=\frac{y+\rho a_{0}}{1+\rho}$, and integrating the budget constraint, it is possible to obtain that $b_{t}=\left(b_{0}+G-\frac{y+\rho a_{0}}{1+\rho}\right) e^{\rho t}$. Under the no-ponzi game condition the central bank is not allowed to announce a policy where it never pays back, in other words, $\lim _{T \rightarrow \infty} b_{T} e^{-\rho T} \leq 0$, which would be violated if $b_{0}+G>\frac{y+\rho a_{0}}{1+\rho}$. As a result, the fixed exchange rate policy would only be possible to implement for a limited amount of time. In this sense, the discussion of a fixed exchange rate mechanism is similar to the analysis under a constraint on reserves, which we turn to next. ${ }^{10}$

\subsection{Constraint on reserves}

Adding a constraint on reserves creates an additional incentive to accumulate reserves before the crisis. The solution is depicted in Figure $4 .^{11}$ The constraint puts a limit on the amount of future revenues that can be transferred to the crisis period. This justifies the jump in consumption, interest rate and inflation when $g_{t}$ reverts back to 0 . Now that the crisis is over the central bank does not need inflation revenues anymore. In fact, the central bank would rather have raised some revenue in these periods, and trans-

\footnotetext{
${ }^{10}$ On the contrary, if $b_{0}+G<\frac{y+\rho a_{0}}{1+\rho}$, this policy would be feasible. Clearly, it would violate the transversality condition for optimality. The optimal policy in this case would be a permanent deflation.

${ }^{11}$ The constrained case is solved in the Online Appendix B.2.
} 

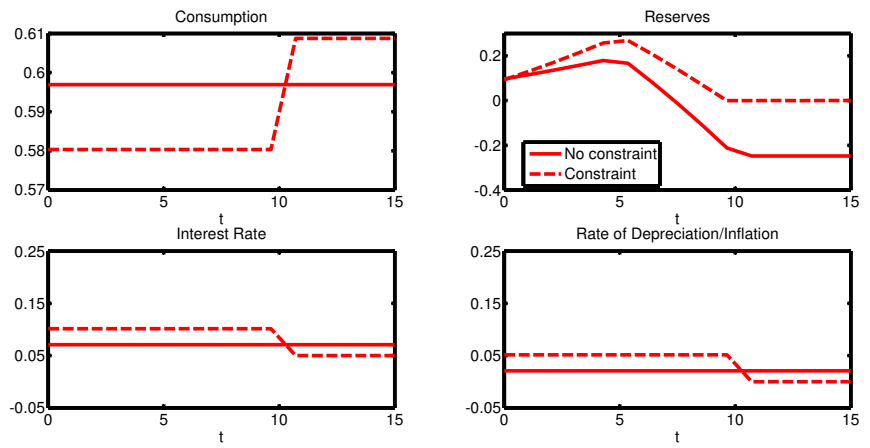

Figure 4: Qualitative comparison between the constrained and the unconstrained economies.

ferred it to the crisis period. But it can not do this because of the borrowing constraint.

Reserve accumulation is represented in the upper right panel, and is plotted against the case without a borrowing constraint. The central bank still wishes to smooth inflation. Because it can not transfer future revenues to the crisis period, it must transfer more present revenues. For this reason, reserves in the constrained case are larger. As a consequence, in the constrained case inflation (and exchange rate depreciation) is larger in the moments preceding the crisis, but smaller when the crisis is over. ${ }^{12}$

\footnotetext{
${ }^{12} \mathrm{~A}$ costlier crisis would see the central bank accumulate more reserves. In this simple deterministic setting, a larger crisis is similar to having larger distortions in the general model. This is the case because in the general model, the expected cost of a crisis depends on the size of the crisis but also on the distortions caused by inflation. If distortions are large, the central bank will have a larger desired level of international reserves.
} 


\section{Numerical Illustration}

In this section I compare the predictions of the model with the data on international reserves. I perform a series of quantitative exercises using data from the period 1970 - 2011. First, I study an average developing economy. I perform the following experiment: a central bank learns at $T=1987$ that the costs of a banking crisis that have to be financed with inflation related revenues have increased. This happened after many years where costs were low. I assume that no other parameter of the economy changed. Faced with the emergence of costlier crises, the central bank needs to reevaluate the adequacy of its reserves stock. I choose 1987 because this is when the average levels of reserves between developed and developing economies start to diverge. It also coincides with a wave of financial liberalization and anticipates an increase in the frequency of banking crises as shown in Figure 2. ${ }^{13}$

I will focus on the average level of reserves obtained after 20 years, depending on different assumptions for parameter values. In a simulation, I show that the build up in reserves is relatively fast. I also show that inflation and exchange rate depreciation are the mirror image of international reserve accumulation. As the stock of international reserves increases, inflation is ever smaller and the exchange rate depreciates. If a crisis hits, the central banks uses a mix of inflation and reserves to finance the necessary expenditures. The larger the reserve holdings at the moment of the crisis, the smaller is the increase in inflation.

\footnotetext{
${ }^{13}$ Note that 1987 is not a special date. A more detailed exercise would try to match precisely the reserve accumulation process for a particular country.
} 
Furthermore, I investigate the effect of the frequency of crises and constraints on borrowing by the central bank. More frequent crises do not greatly increase the level of reserves. This is intuitive. If a crisis hit every period, then crises were already smooth and there is no role for reserve policy. Reserves are most useful when crises are rare and large. Borrowing constraints, however, play an important role. Contingent borrowing is a substitute for reserve accumulation. The more a central bank can borrow from abroad, the smaller will be reserve accumulation.

\subsection{An average developing economy}

In Table 1 I report values for the parameters used in the baseline case. The parameter for the real interest rate $\rho$ corresponds to the US 3-month T-Bill 1970-2010 average. I compute the probability of a crisis $q_{L}$ as the probability of experiencing a banking crisis conditional on not being in a banking crisis. Using the data from Laeven and Valencia (2013) I obtain $3.7 \%$ for developing economies, and 3.8\% for the full sample, which I round up to $4 \%$. The parameter governing the probabilistic end of the crisis $q_{H}$ is computed to match the median duration of a banking crisis in developing economies of 2 years. To calibrate $a_{0}$ I compute average wealth in developing economies in 1987 and subtract central bank reserves. Wealth is computed as the sum of capital stocks and net foreign assets. Capital stocks are computed using the perpetual inventory method and data from the Penn World Table Version 6.2 (Heston et al. (2006)), while net foreign assets are obtained from the database on the External Wealth of Nations by Lane and Milesi-Ferretti (2007). Finally, I calibrate $\alpha=0.22$ obtained from the sample mean for developing countries in 1987 as $\alpha=m / c$. 


\begin{tabular}{ccll}
\hline \hline & Value & Description & Source \\
\hline \hline$\triangle g$ & $10 \%$ GDP & Central bank financing & Burnside et al. (2006) \\
$a_{0}$ & $110.5 \%$ GDP & Net Wealth -Reserves & Sample average WDI 1987 \\
$\rho$ & 0.055 & Real interest rate & US 3-month T-Bill 1970-2010 avg \\
$\alpha=m / c$ & 0.22 & Velocity parameter & Sample average WDI 1987 \\
$q_{L}$ & 0.04 & Probability of a crisis & Laeven and Valencia (2013) \\
$q_{H}$ & 0.5 & Probability of crisis solution & Laeven and Valencia (2013) \\
$\underline{r}$ & 0 & Minimum reserves as \% of GDP & Range -50\% to 0\% \\
\hline \hline
\end{tabular}

Table 1: Baseline parameters for an average developing economy.

Two crucial parameters are the financing needs in the low and in the high spending states. I normalize $g_{L}=0$, and take $g_{H}$ to be $10 \%$ of $G D P$. Table 2 presents available evidence of the fiscal costs of bailing out the banking system in developing economies. The relevant cost for this exercise is the amount accruing to the central bank, that needs to be financed with inflation related revenues. Burnside et al. (2006) perform 3 case studies: Korea 19972002, Mexico 1994-2002 and Turkey 2001-2002. They find that in these three episodes total inflation-related financing up to 2002 was in present value around $20 \%$ of pre-crisis $G D P .^{14}$

Figure 5 shows the optimal inflation rate policy for the central bank as a

\footnotetext{
${ }^{14}$ These costs are in line with previous work on international reserves. Previous literature has focused on output shocks and sudden stops of capital inflows. Jeanne and Ranciere (2011) assume that a representative agent loses access to foreign debt of $10 \%$ of GDP and suffers an output loss of $6.5 \%$ of trend GDP. Alfaro and Kanczuk (2009) assume an output loss of $10 \%$ during a default crisis.
} 


\begin{tabular}{cccc}
\hline \hline Country & Date of Estimate & Fiscal cost of banking crises & Inflation financed \\
\hline \hline Indonesia & Nov. 99 & 65 & - \\
Korea & Dec. 99 & 24 & 22.3 \\
Malaysia & Dec. 99 & 22 & - \\
Mexico & Nov. 94 & 15 & 24 \\
Thailand & Jun. 99 & 35 & - \\
Turkey & Jan. 01 & 18 & 19.2 \\
\hline \hline
\end{tabular}

Table 2: Data from Burnside et al. (2001) and Burnside et al. (2006), present value, $\%$ of pre-crisis GDP.

function of the amount of reserves using the baseline parameters described in Table 1, and compares it to non-optimizing flexible inflation rates. The red interior lines represent optimal policy, while the outer black lines represent flexible policy. We can see that the optimal policy prescription is quite simple. In a state of low expenditure the central bank implements an inflation rate above the flexible policy, and therefore accumulates international reserves. If a crisis hits and expenditure is high, the central bank increases the inflation rate but less than what would be prescribed by a flexible policy. While a crisis persists, the central bank is spending reserves. It will do so until it hits the constraint. Then it is forced to increase the inflation rate and float the exchange rate.

Figures 6 and 7 show the path of reserves and inflation/exchange rate depreciation before and after a crisis. In Figure 6 it is possible to see that in the absence of a crisis, reserves accumulate rather fast. In 20 years, they approach 30\% of GDP. The way accumulation is done is through a decreasing 


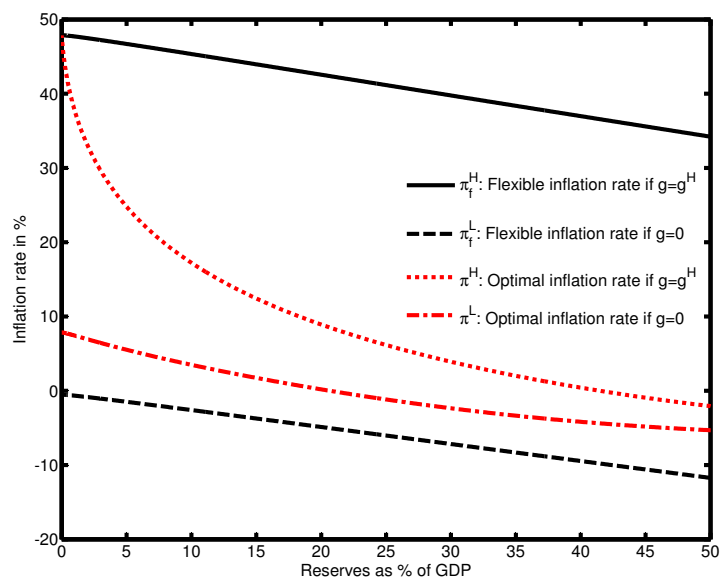

Figure 5: Optimal inflation rate as a function of reserves for baseline calibration.

inflation rate, which translates into a depreciating exchange rate. The reason why inflation is negative is because as the central bank accumulates the optimal stock of reserves it can approach its optimal policy: the Friedman rule. This accumulation of assets does not come without costs. In this simple model, any savings by the central bank directly reduces consumption.

Figure 7 shows the effect of crises on reserves, inflation and exchange rates. This figure describes two crises. The first crisis hits in 1996 at a time when reserves are high. For four years, inflation is larger and reserves go down quickly. The second crisis hits in 2006, when reserves are low. Note how this crisis is accompanied by a larger inflation rate relative to 1996 . In 1996, the inflation rate was about 10\%. In 2006, it immediately approached $20 \%$. Larger inflation is associated with larger exchange rate depreciation. ${ }^{15}$

\footnotetext{
${ }^{15}$ Interestingly, looking at the banking crisis in 2007-08, Obstfeld et al. (2009) shows that countries with larger international reserve holdings devalued their currencies less (and in
} 

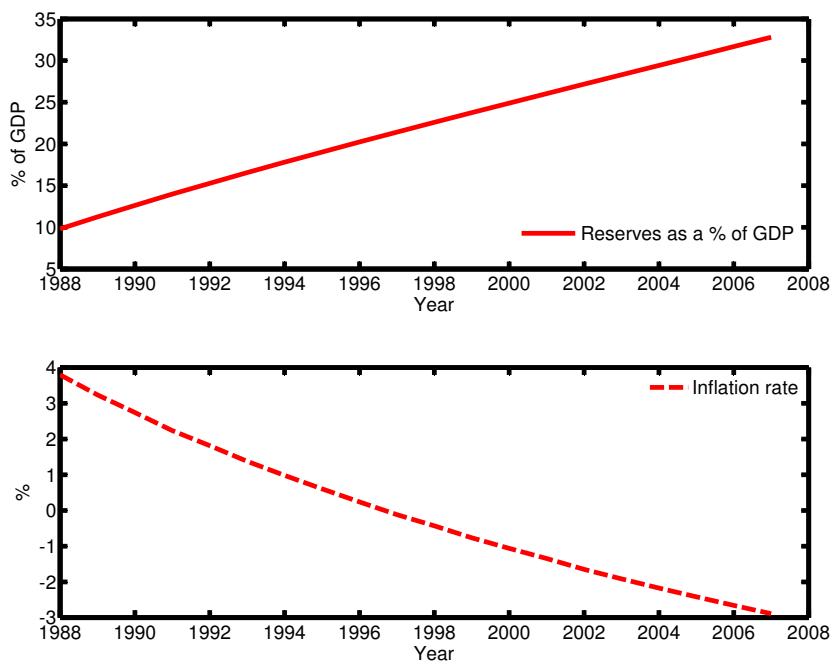

Figure 6: Reserves and inflation rate on the reserve accumulation path.

\subsection{Sources of variation and reserves in 2007}

This section explores the determinants of the stock of international reserves suggested by the model. I simulate the model 1000 times and compute average level of reserves depending on different parameter assumptions. Figure 8 shows a sensitivity analysis for variations in the borrowing constraint of the central bank. The ability to borrow in the event of a crisis is also an important difference between developed and developing economies. In

some cases even saw their currencies appreciate). Dominguez et al. (2012) shows that countries drew from international reserves and allowed for some currency depreciation following the 2007-08 banking crisis. What kept exchange rates from depreciating further was the use of reserves. These authors argue that precautionary motives were behind this decision, as a mercantilist policy would rather see the currency depreciate even more. 

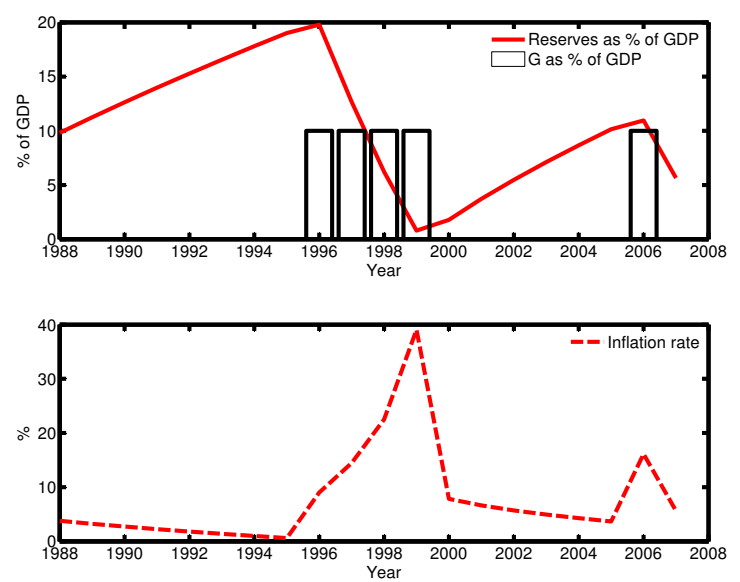

Figure 7: Reserves and inflation during two crises.

the 2008 crisis, some central banks established swap lines between them, to ensure liquidity of foreign currency in a period of distress. Central banks in developing economies could not access these credit lines (Obstfeld et al. (2009)). As expected, increased international borrowing by central banks is associated with lower levels of international reserves, as shown in Figure 8.

The analysis so far has considered large and infrequent crisis. How do these compare with costlier but less frequent crises? Figure 9 collects the level of reserves after 20 years for different combinations of frequency and size of crises. It shows that the existence of large reserves is the consequence of large and infrequent crises. The larger the size of the crisis, the larger are reserves. More frequent crises also increase reserves but at a decreasing rate. This is intuitive, if crises are very frequent there is less of a role for reserves as a smoothing policy.

To sum up, the quantitative analysis of the model shows that reserves 


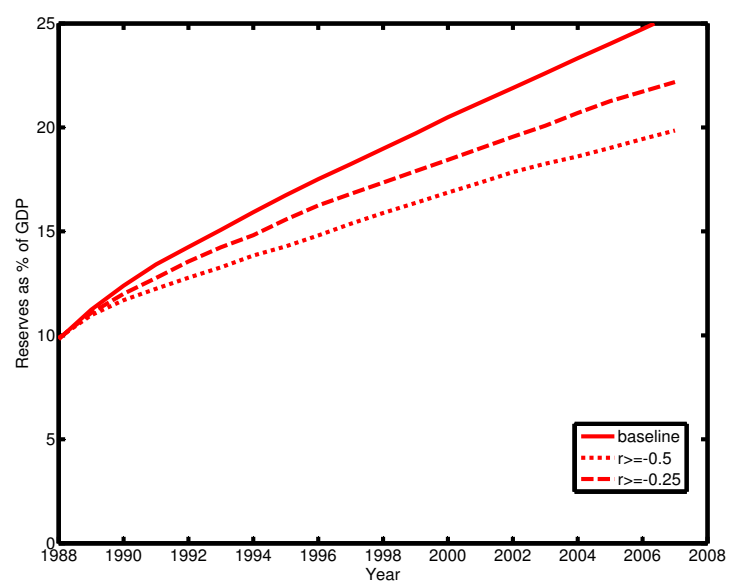

Figure 8: Reserves in 2007 under different parameter assumptions for reserves constraint.

adequacy should be measured with respect to the magnitude of the financing needs and the ability to access contingent financing following a crisis.

\subsection{Discussion}

In this section I provided a quantitative illustration of the monetary perspective. This paper has argued that this perspective is useful to understand the level of reserves observed in the data but it should be noted that both the model and the quantitative exercise were simple and should be seen as an introduction to the monetary perspective of reserve accumulation. I now discuss some of the issues regarding the exercise and present some evidence about the importance of the monetary perspective when studying reserves.

In the model all inflation related revenues take the form of seigniorage. Burnside et al. (2006) argue that, at least for the cases of Korea, Mexico and Turkey, only a limited part of the bailouts were financed through this means. 


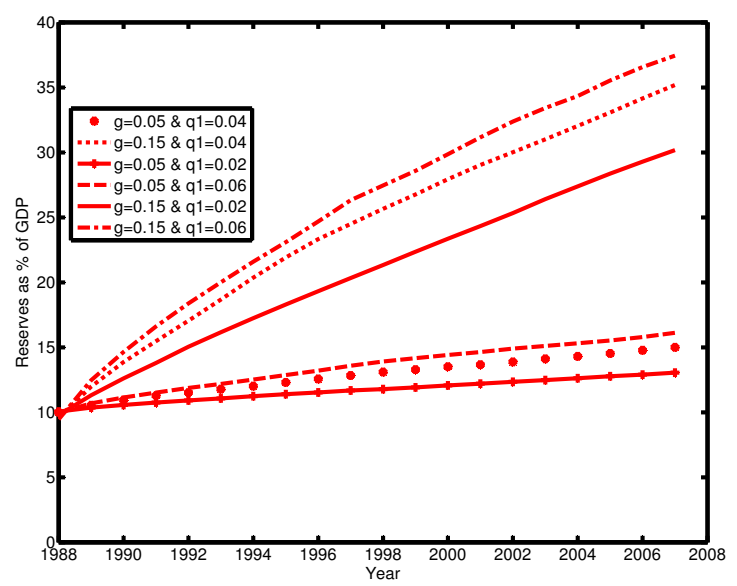

Figure 9: Reserves in 2007 under different parameter assumptions for costs and probability of a crisis.

They highlight the role of other inflation related revenues that I abstract from in this paper: deflating nominal debt and an implicit devaluation; but also fiscal reforms. If these other inflation related revenues are less costly than seigniorage, then the exercise performed in this section would overestimate reserves and inflation. At the same time, the costs used in the quantitative exercise do not include the part financed with reserves, and therefore underestimate the real amount financed by the central bank. Furthermore, the model has no capital and featured log-utility. In a more sophisticated model, there would be distortions associated with inflation that would increase the costs associated with both accumulation of reserves and raising inflation related revenues during a banking crisis. ${ }^{16}$

\footnotetext{
${ }^{16}$ See Rodrik (2006) for an estimation of the cost of reserves. Adding capital and moving away from log-utility would also create a role for a Laffer curve for inflation. Currently, the
} 
I turn now to the question whether central banks accumulate international reserves due to prospective spending needs and whether they use reserves to support the banking sector during a banking crisis. This view is shared by Dominguez et al. (2012), who highlight the role of international reserves as a facility for a lender of last resort, as well as by Obstfeld et al (2010), who interpret their finding that $M 2 / G D P$ is correlated with international reserves as evidence for reserves being held to support the financial sector. In the Online Appendix C, I look at three interesting emerging economies that had accumulated significant international reserves (in parentheses as \% of GDP) before the financial crisis of 2007: Brazil (13.13\%), Russia (35.91\%) and Korea (24.98\%); and analyze policies implemented in 2008. I find that international reserves were used in order to maintain financial stability, including direct banking sector support. In the Online Appendix C, I also explore the full cross-country evidence and test whether lagged size of the financial sector is correlated with the probability of experiencing a banking crisis. The marginal effect of lagged size of the financial sector on the probability of experiencing a banking crisis is positive and significant at the $5 \%$ level. These results complement the results by Obstfeld et al. (2010). Together, they describe a world where the amount of reserves held by the central bank is calculated with respect to the size of the banking sector, and where larger banking sectors are correlated with more frequent banking crises.

model is such that the consumer spends the same in consumption every period, regardless of inflation. Therefore, the Laffer curve never slopes down. 


\section{Conclusion and future research}

In the last 20 years, central banks in developing economies have accumulated an unprecedented level of international reserves. The level of reserves in these countries now exceeds $25 \%$ of GDP if you include gold. This has been puzzling for academics and policy makers. In this paper, I have ex-

plored a view where international reserve accumulation is the consequence of long-run central bank policy. This monetary perspective contributes to our understanding of this phenomenon in different dimensions.

First, it formalizes one motive for reserve accumulation by central banks. I have argued that reserve adequacy should be measured with respect to things that central banks do in developing economies: inflation and exchange rate management and financial sector support during crises. Reserve accumulation is the outcome of constrained optimal policy. Central banks weight the costs of reserves against the benefits associated with avoiding massive disruptions in their economies during crises. That is not to say that this situation is desirable from a global perspective. Ultimately, international reserve accumulation reflects the existence of large shocks, and the absence or imperfection of international insurance markets. Two immediate policy objectives follow from this analysis: reducing the magnitude of shocks, and improving international insurance markets. Neither of these is trivial, but the recent accumulation of international reserves should be understood with these in the background.

Second, this view has predictions for the behavior of exchange rates that are consistent with the data. Reserve accumulation in this paper is associated with a depreciating currency. Also, during a crisis, the central bank uses 
reserves to fight depreciation. We observe the two in the data (see LevyYeyati et al. (2013), Aizenman and Sun (2012), Dominguez et al. (2012) and Obstfeld et al. (2009)). The first of these facts has been used to argue that reserve accumulation is the unintended consequence of trade policy that tries to promote exports and growth (Benigno and Fornaro (2012)). The relative importance of trade and monetary policies remains an unresolved debate, as discussed in Levy-Yeyati and Sturzenegger (2010). But it is still noteworthy that the monetary perspective can rationalize the two facts, which can guide future empirical work on this important question.

Third, I have highlighted important factors behind the accumulation of international reserves in different countries. The model predicts that distortions associated with inflation, the magnitude of crisis and how stringent are central bank borrowing constraints, all determine the level of international reserves in developing economies. This list is by no means exhaustive. Future work could enrich the model to fully explore the heterogeneity of reserve accumulation experiences across countries. It should also introduce short-run considerations. Introducing nominal rigidities and breaking down the purchasing power parity assumption would create short-run predictions for exchange rates and reserves that could be tested.

Finally, this paper has focused on a world where exogenous banking crises require the central bank to support the government and the financial sector. Both assumptions can be endogeneized in a model a la Diamond and Dybvig (1983). Central bank policies may affect directly the magnitude or likelihood of banking crises, for example, through their effect on capital flows and the fueling of asset bubbles. Introducing interactions between the central bank 
and the fiscal authority would highlight the co-movement of reserves, government and private debt. In this paper, I have used a partial equilibrium, small open economy model to introduce the monetary perspective on this important question. This hardly exhausts the discussion on reserves, and should be viewed as a complementary explanation to others discussed in this paper. A thorough analysis of all these factors is essential to our understanding of modern financial architecture, and remains an exciting field of research.

Acknowledgments: I am grateful to Jaume Ventura for his guidance and support. I thank Paulo Abecasis, Fernando Broner, Vasco Carvalho, Alberto Martin and Robert Zymek for helpful comments and suggestions. I also thank seminar participants of the CREi International Lunch at Universitat Pompeu Fabra, University of Valencia, EBS Business School, University of Amsterdam, University of Konstanz, Federal Reserve Board, Santa Clara University, Bank of Spain, Collegio Carlo Alberto, Bank of Norway, as well as participants of the European Economic Association 2011 Congress, the ISNE Meeting 2010 in Dublin, the ASSET Meeting 2010 in Alicante and the Spanish Economic Association 2011 Congress. I would also like to thank the Fundação para a Ciência e a Tecnologia (SFRH/BD/24730/2005) for financial support.

Aizenman, Joshua and Nancy Marion, "International Reserve Holdings with Sovereign Risk and Costly Tax Collection," The Economic Journal, 2004, 114 (497), 569-591.

- and Yi Sun, "The financial crisis and sizable international reserves depletion: From fear of floating to the fear of losing international reserves?," International Review of Economics \&3 Finance, 2012, 24, 250-269. 
Alfaro, Laura and Fabio Kanczuk, "Optimal reserve management and sovereign debt," Journal of International Economics, 2009, 77 (1), 23-36.

Barro, Robert J, "On the determination of the public debt," The Journal of Political Economy, 1979, pp. 940-971.

Benigno, Gianluca and Luca Fornaro, "Reserve accumulation, growth and financial crises," 2012.

Bianchi, Javier, Juan Carlos Hatchondo, and Leonardo Martinez, "International Reserves and Rollover Risk," 2014.

Broner, Fernando, "Discrete devaluations and multiple equilibria in a first generation model of currency crises," Journal of Monetary Economics, 2008, $55(3), 592-605$.

_, Tatiana Didier, Aitor Erce, and Sergio L Schmukler, "Gross capital flows: Dynamics and crises," Journal of Monetary Economics, 2013, $60(1), 113-133$.

Brutti, Filippo, "Sovereign defaults and liquidity crises," Journal of International Economics, 2011, 84 (1), 65-72.

Burnside, Craig, Martin Eichenbaum, and Sergio Rebelo, "Prospective Deficits and the Asian Currency Crisis," Journal of Political Economy, 2001, 109 (6), 1155-1197.

_ , , and _ , "Government finance in the wake of currency crises," Journal of Monetary Economics, 2006, 53 (3), 401-440. 
Bussière, Matthieu, Gong Cheng, Menzie D Chinn, and Noëmie Lisack, "For a few dollars more: Reserves and growth in times of crises," Journal of International Money and Finance, 2015, 52, 127-145.

Calvo, Guillermo A, "Balance of payments crises in a cash-in-advance economy," Journal of Money, Credit and Banking, 1987, pp. 19-32.

Diamond, Douglas W and Philip H Dybvig, "Bank runs, deposit insurance, and liquidity," The Journal of Political Economy, 1983, pp. 401-419.

Dominguez, Kathryn ME, Yuko Hashimoto, and Takatoshi Ito, "International reserves and the global financial crisis," Journal of International Economics, 2012, 88 (2), 388-406.

Durdu, Ceyhun Bora, Enrique G Mendoza, and Marco E Terrones, "Precautionary demand for foreign assets in Sudden Stop economies: An assessment of the New Mercantilism," Journal of Development Economics, 2009, 89 (2), 194-209.

Flood, Robert $\mathbf{P}$ and Peter M Garber, "Collapsing exchange-rate regimes: some linear examples," Journal of International Economics, 1984, $17(1), 1-13$.

Forbes, Kristin J and Francis E Warnock, "Capital flow waves: Surges, stops, flight, and retrenchment," Journal of International Economics, 2012, 88 (2), 235-251.

Gennaioli, Nicola, Alberto Martin, and Stefano Rossi, "Sovereign default, domestic banks, and financial institutions," The Journal of Finance, 2014, 69 (2), 819-866. 
Greenspan, Alan, "Currency reserves and debt," in "Remarks before the World Bank Conference on Recent Trends in Reserves Management, Washington, DC (April 29)" 1999.

Heston, Alan, Robert Summers, and Bettina Aten, "Penn World Table Version 6.2, center for International Comparisons of Production," Income and Prices at the University of Pennsylvania, 2006.

Jeanne, Olivier and Romain Ranciere, "The Optimal Level of International Reserves For Emerging Market Countries: A New Formula and Some Applications*," The Economic Journal, 2011, 121 (555), 905-930.

Krugman, Paul, "A model of balance-of-payments crises," Journal of Money, Credit and Banking, 1979, pp. 311-325.

Kumhof, Michael, Ricardo Nunes, and Irina Yakadina, "Simple Monetary Rules under Fiscal Dominance," Journal of Money, Credit and Banking, 2010, 42 (1), 63-92.

Laeven, Luc and Fabian Valencia, "Systemic banking crises database," IMF Economic Review, 2013, 61 (2), 225-270.

Lane, Philip R and Dominic Burke, "The empirics of foreign reserves," Open Economies Review, 2001, 12 (4), 423-434.

_ and Gian Maria Milesi-Ferretti, "The external wealth of nations mark II: Revised and extended estimates of foreign assets and liabilities, 19702004," Journal of International Economics, 2007, 73 (2), 223-250. 
Levy-Yeyati, Eduardo and Federico Sturzenegger, "Monetary and exchange rate policies," Handbook of Development Economics, 2010, 5, 42154281.

_ , _, and Pablo Alfredo Gluzmann, "Fear of appreciation," Journal of Development Economics, 2013, 101, 233-247.

Obstfeld, Maurice, Jay C Shambaugh, and Alan M Taylor, "Financial Instability, Reserves, and Central Bank Swap Lines in the Panic of 2008," The American Economic Review, 2009, pp. 480-486.

${ }_{-},{ }_{-}$, and _, "Financial Stability, the Trilemma, and International Reserves," American Economic Journal: Macroeconomics, 2010, 2(2), 57-94.

Rebelo, Sergio and Carlos A Végh, "When is it optimal to abandon a fixed exchange rate?," The Review of Economic Studies, 2008, 75 (3), 929-955.

Reinhart, Carmen M and Kenneth S Rogoff, "This time is different: A panoramic view of eight centuries of financial crises," Technical Report, National Bureau of Economic Research 2008.

Rigobon, Roberto, "Disinflation and fiscal reform: A neoclassical perspective," Journal of International Economics, 2002, 58 (2), 265-297.

Rodrik, Dani, "The social cost of foreign exchange reserves," International Economic Journal, 2006, 20 (3), 253-266. 